\title{
New PAX2 heterozygous mutation in a child with chronic kidney disease: a case report and review of the literature
}

\author{
Li Zhang, Shu-bo Zhai ${ }^{*}$ (D, Leng-yue Zhao, Yan Zhang, Bai-chao Sun and Qing-shan Ma
}

\begin{abstract}
Background: We herein report a 3-year-old boy presented with chronic kidney disease (CKD) due to PAX2 missense mutation (C to $\mathrm{G}$ transversion at position 418 in exon 4).

Case presentation: He attended our clinic with a 3-month history of foamy urine. Upon examination, he had reduced estimated glomerular filtration rate (GFR) and renal atrophy. Genetic investigations revealed that he has inherited a mutated PAX2 gene from his father, who had renal failure at the age of 20 . We searched the literature and confirmed that this mutation site has not been reported by any other group before.

Conclusions: Although renal coloboma syndrome (RCS) with simultaneous kidney and eye involvement is the most common phenotype of PAX2 mutations, current literature supports that such mutations may have profuse clinical manifestations and renal hypoplasia is one distinct entity in the spectrum.
\end{abstract}

Keywords: PAX2 mutation, Chronic kidney disease, Child, Hypoplasia

\section{Background}

CKD is a serious condition in children that leads to significant morbidity and mortality. The prevalence of end stage renal disease (ESRD) among children aged 19 years and younger in United States was 12.9 per million/year [1]. In contrast to the adult population, obstructive uropathy and congenital renal aplasia/hypoplasia/dysplasia are responsible for almost one half of all cases of CKD in children [2]. Recent studies have shown that PAX2 gene plays critical roles in organogenesis during embryonic development, and the PAX2 mutation is the most common cause of renal hypoplasia [3]. The complete ablation of $P A X 2$ stunts renal organogenesis at early stage of kidney development and can result in kidney agenesis [4]. The most common renal phenotype caused by mutation of PAX2 is renal coloboma syndrome (OMIM \#120330; also known as papillorenal syndrome). In this report, we present a child with CKD caused by renal hypoplasia. Genetic investigation confirmed that he had a

\footnotetext{
* Correspondence: jelly4sci@sina.com

Department of Pediatrics Nephrology, First Hospital, Jilin University, Changchun, Jilin 130021, China
}

mutation in the $P A X 2$ gene that had not been reported in the literature before.

\section{Case presentation}

A 3-year-old boy presented to our hospital with a 3 -month history of foamy urine. He was born at gestational age of 36 weeks 6 days to a young couple with no history of consanguinity. Prior history was significant for decreased amniotic fluid volume, which was detected since gestational age of 5 months. According to the mother, fetal ultrasonography at that time was suggestive of renal malformation without exact details. Otherwise, he had been free of any significant illnesses including hepatitis B, tuberculosis, IgA vasculitis or systemic lupus erythematosus. His father had been diagnosed with "nephritis and kidney failure" at the age of 20 and had an allograft kidney transplantation for 10 years. Upon presentation, his vital signs and physical examinations, including eye examinations, were normal. The results of relevant investigations were depicted in Table 1. In summary, he had proteinuria, elevated levels of BUN and creatinine, hyperparathyroidism, acidosis and bilateral renal atrophy. Genetic study showed a heterozygous mutation in the PAX2 gene. Further studies on the family 
Table 1 Relevant abnormalities in laboratory investigations

\begin{tabular}{lll}
\hline Laboratory Investigation & Results & Normal range \\
\hline Urea nitrogen $(\mathrm{mmol} / \mathrm{L})$ & $13.1 \sim 15.4$ & $2.86-7.14$ \\
Creatinine $(\mathrm{umol} / \mathrm{L})$ & $83.5 \sim 90.0$ & $28.3 \pm 6.2$ \\
Parathyroid Hormone $(\mathrm{g} / \mathrm{ml})$ & 135.8 & $12.0-88.0$ \\
Blood $\mathrm{CO}_{2}$ level $(\mathrm{mmol} / \mathrm{L})$ & 16.2 & $23-31$ \\
Renal ultrasonography $(\mathrm{mm} \times \mathrm{mm})$ & Left: $53 \times 21 ;$ & Left:(65.5-73.5) $\times(32.7-36.9) ;$ \\
& Right: $49 \times 25$ & Right:(60.7-68.3) $\times(32.3-35.7)$ \\
$99 \mathrm{mTC}-D T P A$ & Whole: $45.42 \mathrm{ml} / \mathrm{min}:$ & \\
& Right: $23.28 \mathrm{ml} / \mathrm{min}$; left: $22.14 \mathrm{ml} / \mathrm{min}$ & \\
Gene study & heterozygous mutation point in PAX2 & \\
& c.418C $>$ G (cytosine $>$ guanine) chr10:102539262 & \\
\hline
\end{tabular}

showed that the patient inherited the mutated gene from his father although no similar mutation was detected in paternal grandparents. The pedigree was shown in Fig. 1 and the gene mappings were shown in Fig. 2a and b.

The child was managed medically by correcting the metabolic derangements secondary to chronic kidney diseases and by monitoring the progress. At last follow up at 1 year, all his initial metabolic changes normalized and his GFR did not deteriorate.

\section{Discussion and conclusions}

CKD is a rapidly growing public health issue, affecting both children and adults globally. It brings physical suffering and inflicts financial burdens to those affected. While most of the adults with CKD are secondary to either hypertension or diabetes, the etiologies of CKD in children are much more heterogenous [5]. While CAKUT (congenital anomalies of kidney and urinary tract) are the

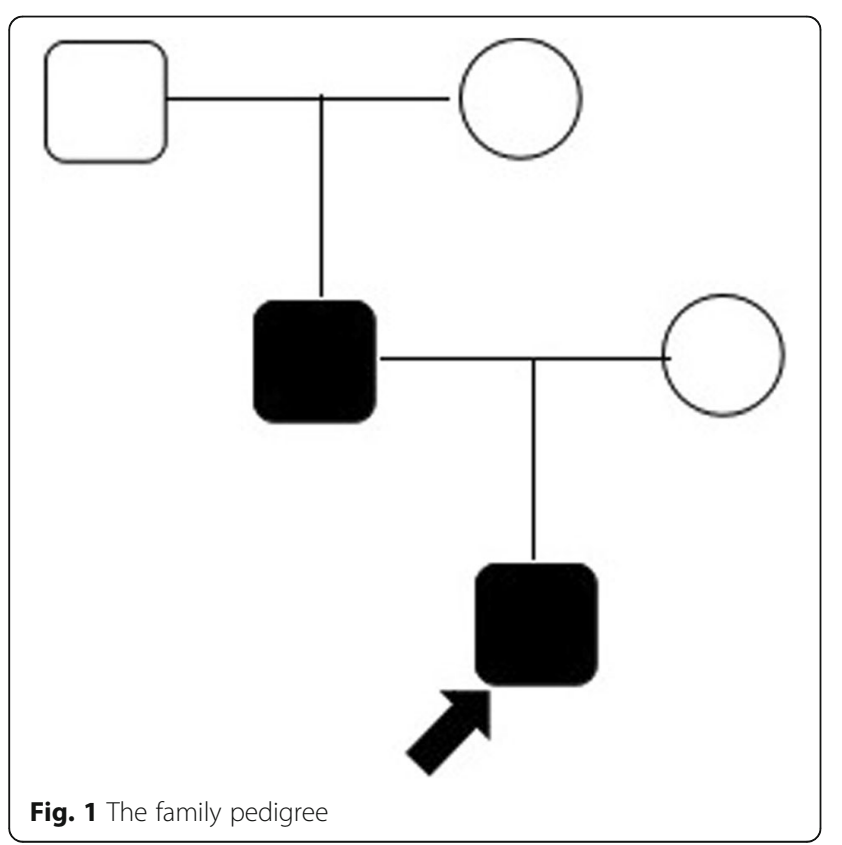

main causes of CKD among children in developed countries, infection-related glomerulonephropathies seem to be the major culprits leading to CKD in the developing world [6]. It is significant to identify the primary disease of CKD, especially in children, which would play an important role to evaluate disease evolution and to guide treatment. Because of the good effect of kidney transplantation in patients with CKD caused by partial genetic factors, we should adequately understand the genotype and phenotype.

Our patient was at the age of 22 months when first presented, and he has already had metabolic acidosis, hyperparathyroidism and renal atrophy. He had an estimated GFR of $45 \mathrm{ml} / \mathrm{min} / 1.73 \mathrm{~m}^{2}$ and his symptoms had lasted for more than 3 months, which rendered him compatible to have a clinical diagnosis of CKD stage 3 [7]. Based on the fact that he had prenatal diagnosis of renal anomalies, reduced amniotic fluid and absence of other obvious etiology for CKD, in addition to having the same genetic mutation in the $P A X 2$ gene as his father, who suffered from end stage renal diseases that required kidney allograft transplantation at early age, we concluded that his underlying cause of CKD was secondary to renal dysplasia associated with the $P A X 2 \mathrm{mu}$ tation (missense mutation, $C$ to $G$ transversion at position 418 in exon 4). The limitation of this approach is that the renal biopsy is not performed. Extend to the analysis to his grandparents, both of them have normal renal function and genotype. It can be concluded that the missense mutation c. $418 \mathrm{C}>\mathrm{G}$ is a de novo mutation in the proband's father, and the proband inherited the mutation from his father. Searching in a web site database for the human PAX2 allelic variant (http:// lsdb.hgu.mrc.ac.uk/pax2.txt), this mutation site has not been contained.

Development of mammalian metanephric kidney begins in early fetal life. The ureteric bud emerges from the Wolffian duct and extends outward towards the metanephros under the influence of trophic signals [8]. 


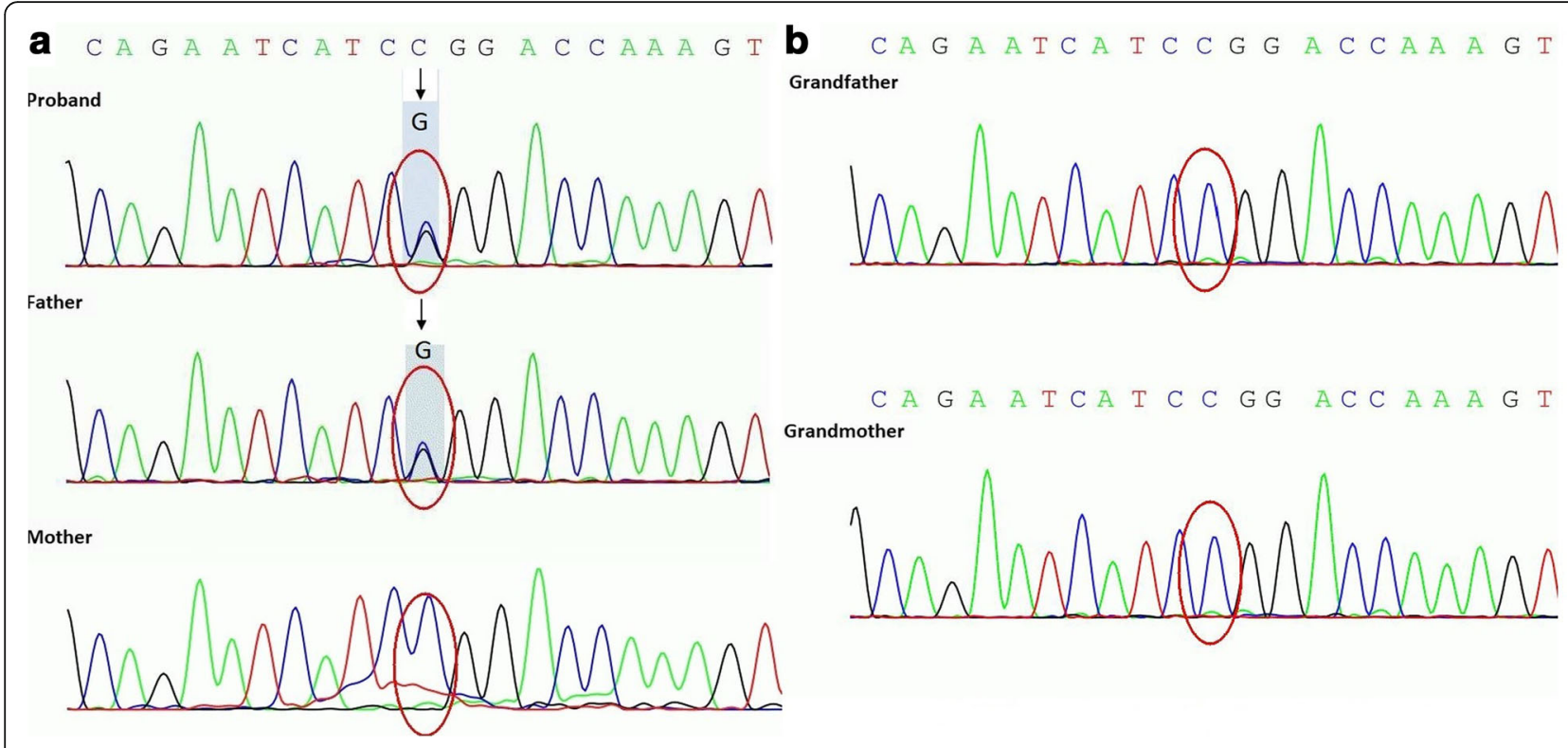

Fig. 2 a The same PAX2 mutation in proband and his father. (c.418C>G, p.R140G, exon4, chr10-102,539,262, NM_000278). b Normal genotype in paternal grandparents

The PAX2 gene is located close to the bands q24 and q25 on chromosome 10, and current data proves that it plays a pivotal role during kidney development. Mutations of $P A X 2$ gene in human and mice models have been associated with multiple renal anomalies, and the most commonly encountered malformation is renal hypoplasia [9]. $P A X 2$ is also expressed during the development of the eye, ear and nervous system. Although PAX2 mutations have been reported mostly in patients with RCS, such mutations have also been identified in patients with congenital anomalies of these systems [10]. In a series of patients suffering from RCS with proven PAX2 mutations, the renal, eye and high frequency hearing loss were found in $92 \%$, $77 \%$ and $7 \%$ of patients, respectively [11]. Adam et al. have also reported a family with members suffering from RCS associated with heterozygous insertion mutation c.228 251dup and p.Ser77_Gly84dup, which had a wide spectrum of phenotypes [12].

The gene mutation site detected in this case has not been reported in the literature so far. Interestingly, our patient and his father both presented with chronic kidney disease without any optic involvement. Besides of renal function and complications of CKD, regular follow-up in ophthalmology and hearing test still will be done for him. We reviewed and summarized other reported cases with PAX2 mutation leading to renal hypoplasia from 2000 to 2016, as depicted in Table 2, in order to observe reported phenotype and genotype of $P A X 2$ mutation, especially whether there is any optic involvement. As shown in Table 2, kinds of different PAX2 mutations, including frame- shift, missense and nonsense mutations can be found in patients with RCS.
Among these, Nishimoto et al. suggested that renal hypoplasia was part of the RCS that was caused by heterozygous mutations of the $P A X 2$ gene [13]. In their study, two novel nonsense mutations are reported. In addition, this is the first case of a PAX2 mutation resulting in isolated renal hypoplasia without ocular involvement. Another patient with deletion in the region $10 \mathrm{q} 23.2 \mathrm{q} 24.3$ on one of the chromosome 10, which led to complete deletion of one PAX2 gene, has also had renal abnormalities without any ocular abnormality [14]. Furthermore, this is the first case of heterozygous $P A X 2$ gene deletion with renal abnormalities without optic coloboma in humans.

In our study, we reported a boy with heterozygous missense mutation of $P A X 2$, that is $\mathrm{C}$ to $\mathrm{G}$ transversion at position 418 in exon 4, which changed arginine 140 to a glycine at the protein level. It is not clear how the change of molecular structure influences the function of gene. Talking about the structure of the gene, we have known that the $P A X 2$ paired domain consists of 2 globular protein sub-domains called $\mathrm{N}$ sub-domain and $\mathrm{C}$ sub-domain and a polypeptide chain between them. The PAX2 $\mathrm{N}$-subdomain (residues 16-74) contains 4 parts of structure as follows, an anti-parallel b-hairpin (residues 16-27) and 3 a-helices, a1 (residues 33-46), a2 (residues 49-57), and a3 (residues 58-74). Relatively, the C-subdomain also includes 3 a-helices, a4 (residues 88-105), a5 (residues 109-120) and a6 (residues 131-146) [15, 16]. AS reported, the C-subdomain is involved in protein-DNA interaction [15], and R140G in our study is located at a6, that may cause a change in the secondary structure of the a6-helix resulting in the loss of protein specificity. It can be 
Table 2 Other reported cases with PAX2 mutations in literature between the years 2000 to 2016

\begin{tabular}{|c|c|c|c|c|c|c|c|c|}
\hline Patient & Age (years) & $\begin{array}{l}\text { Renal } \\
\text { hypoplasia }\end{array}$ & $\begin{array}{l}\text { Renal } \\
\text { insufficiency }\end{array}$ & $\begin{array}{l}\text { Optic nerve } \\
\text { colobama }\end{array}$ & VUR & PAX2 mutation & Year & Reference \\
\hline 1 & 7 & + & + & + & + & exon 2619 ins $G$ & 2000 & [20] \\
\hline $2-1$ & 8 & + & + & - & + & exon 91566 C > A (novel) & 2001 & [13] \\
\hline $2-2$ & 4 & + & + & Right+;Left - & - & exon 71318 C > T (novel) & 2001 & [13] \\
\hline $3-1$ & 6 & + & + & + & unknown & 832 del G & 2001 & [21] \\
\hline $3-2$ & 37 & + & + & + & unknown & 832 del G & 2001 & [21] \\
\hline $3-3$ & 12 & + & - & + & unknown & 619 ins $G$ & 2001 & [21] \\
\hline $3-4$ & 11 & + & +- & + & unknown & 619 ins $\mathrm{G}$ & 2001 & [21] \\
\hline $3-5$ & 10 & + & +- & + & unknown & 619 ins $G$ & 2001 & [21] \\
\hline $3-6$ & 15 & + & - & + & unknown & 619 ins $G$ & 2001 & [21] \\
\hline $3-7$ & 19 & + & +- & + & unknown & 658-663 del & 2001 & [21] \\
\hline $3-8$ & 17 & + & - & + & unknown & 619 ins $G$ & 2001 & [21] \\
\hline $3-9$ & 29 & + & - & + & unknown & 619 ins $\mathrm{G}$ & 2001 & [21] \\
\hline 4 & 9 & + & + & + & unknown & exon 2602 del T (novel) & 2001 & [22] \\
\hline $5-1$ & 34 & + & + & + & - & exon $2755 \mathrm{G}>\mathrm{C}$ & 2005 & {$[23]$} \\
\hline $5-2$ & Mother of 5-1 & + & + & + & - & exon $2755 \mathrm{G}>C$ & 2005 & [23] \\
\hline $6-1$ & $21, \| 1-3$ & + & + & + & - & exon 2 (682-691) del CAGGGTGTGC & 2005 & [24] \\
\hline $6-2$ & $3,|1|-3$ & + & + & - & + & exon 2 (682-691) del CAGGGTGTGC & 2005 & [24] \\
\hline $6-3$ & $24,|1|-4$ & + & + & + & - & exon 2 (682-691) del CAGGGTGTGC & 2005 & {$[24]$} \\
\hline $6-4$ & $3, I V-1$ & + & + & + & - & exon 2 (682-691) del CAGGGTGTGC & 2005 & [24] \\
\hline $6-5$ & $0.5, \vee-2$ & + & + & + & - & exon 2 (682-691) del CAGGGTGTGC & 2005 & [24] \\
\hline $6-6$ & $0.5, V-2$ & + & + & + & - & exon 2 (682-691) del CAGGGTGTGC & 2005 & [24] \\
\hline $7-1$ & 21 & + & + & + & - & exon 2619_620 ins G & 2007 & [25] \\
\hline $7-2$ & 17 & + & - & + & - & exon 2619_620 ins G & 2007 & {$[25]$} \\
\hline $7-3$ & 11 & + & - & + & - & exon 2619_620 ins G & 2007 & {$[25]$} \\
\hline $7-4$ & 15 & + & + & + & - & exon 2619_620 ins G & 2007 & [25] \\
\hline $7-5$ & 2.5 & + & - & + & - & exon 2619_620 ins G & 2007 & {$[25]$} \\
\hline $7-6$ & 11 & + & - & + & - & exon 3 p.R $104 \times$ & 2007 & [25] \\
\hline 8 & 5 month & + & + & - & - & del (10) (q23.2q24.3) & 2007 & [14] \\
\hline 9 & 19 & + & + & + & + & exon 3 c.853 C> T (p.R104X) & 2008 & {$[26]$} \\
\hline 10 & 1 month & + & + & + & unknown & exon 2619 ins $G$ & 2010 & [27] \\
\hline 11 & $<1$ & + & + & + & + & exon 2 del (10q24.2q24.32) & 2012 & {$[28]$} \\
\hline 12 & 8 & + & + & + & - & exon 2 del (10q24.31) & 2012 & {$[29]$} \\
\hline 13 & 61 & + & + & + & - & exon 3 c.228_251 dup & 2013 & {$[12]$} \\
\hline $14-1$ & unknown & + & + & + & unknown & exon 2 c.119-120 del GC & 2015 & [30] \\
\hline $14-2$ & unknown & + & + & + & unknown & exon 2 c.119-120 del GC & 2015 & [30] \\
\hline $14-3$ & unknown & + & + & + & unknown & exon 2 c.119-120 del GC & 2015 & [30] \\
\hline $14-4$ & unknown & + & + & + & unknown & exon 2 c.119-120 del GC & 2015 & {$[30]$} \\
\hline $14-5$ & unknown & + & + & + & unknown & exon 2 c.119-120 del GC & 2015 & {$[30]$} \\
\hline $14-6$ & unknown & + & + & + & unknown & exon 2 c.212G $>C$ & 2015 & {$[30]$} \\
\hline $14-7$ & unknown & + & + & + & unknown & exon 2 c. $212 \mathrm{G}>\mathrm{C}$ & 2015 & [30] \\
\hline $14-8$ & unknown & + & + & + & unknown & exon 9 c.1023C $>A$ & 2015 & {$[30]$} \\
\hline $14-9$ & unknown & + & + & + & unknown & exon 2 c.187G >A & 2015 & {$[30]$} \\
\hline $14-10$ & unknown & + & + & + & unknown & exon 2 c.57-58 ins GTGAACC & 2015 & {$[30]$} \\
\hline
\end{tabular}


Table 2 Other reported cases with PAX2 mutations in literature between the years 2000 to 2016 (Continued)

\begin{tabular}{|c|c|c|c|c|c|c|c|c|}
\hline Patient & Age (years) & $\begin{array}{l}\text { Renal } \\
\text { hypoplasia }\end{array}$ & $\begin{array}{l}\text { Renal } \\
\text { insufficiency }\end{array}$ & $\begin{array}{l}\text { Optic nerve } \\
\text { colobama }\end{array}$ & VUR & PAX2 mutation & Year & Reference \\
\hline$\overline{14-11}$ & unknown & + & + & + & unknown & exon 3 c.224-225insAC & 2015 & {$[30]$} \\
\hline $15-1$ & 27 & + & + & - & + & exon 2 c.76dupG (p.Val26Glyfs*28) & 2016 & {$[31]$} \\
\hline $15-2$ & 2 & + & + & - & - & exon 2 c.76dupG (p.Val26Glyfs*28) & 2016 & [31] \\
\hline $15-3$ & $<1$ & + & + & - & - & exon 2 c.76dupg (p.Val26Glyfs*28) & 2016 & [31] \\
\hline
\end{tabular}

inferred that a partially-functional or abnormally-functional protein product is made in vivo due to this kind of missense mutation, therefore the entire kidney development process is seriously affected.

Dressler et al. have done lots of researches to observe and prove the relationship between abnormal expression of PAX2 and renal epithelial cells development [17, 18]. In addition, Ostrom et al. also proven the role that $P A X 2$ maintains cystic renal epithelia [19]. In light of the significant role of $P A X 2$ in nephrogenesis, it is possible that its failed expression in the mutant could contribute to renal hypoplasia with reduced number of glomeruli or complete renal agenesis causing decreased renal function even CKD.

Considering the function of filtration and incretion of kidney, the child was managed medically by correcting the metabolic derangements secondary to CKD (anemia, metabolic acidosis and hyperparathyroidism) and by monitoring the progress. Renal replacement therapy needs to be considered once reaching ESRD.

Therefore, current literature supports that PAX2 mutations may have diverse clinical manifestations and renal hypoplasia is one distinct entity in the spectrum. Hence, genetic screening in patients with CAKUT is recommended. Although our patient is stable with medical therapy at this moment, he is being followed up closely to ensure timely intervention if his clinical condition changes.

\section{Abbreviations}

CAKUT: Congenital anomalies of kidney and urinary tract; CKD: Chronic kidney disease; ESRD: End stage renal disease; GFR: Glomerular filtration rate; PAX2: Paired box 2; RCS: Renal coloboma syndrome

\section{Acknowledgements}

We thank the patient, his family and authors who participated in this study. At the same time, we thank Professor Keithk Lau of University of Hong Kong for revising the language of the article.

\section{Availability of data and materials}

The datasets used analyzed during the current study are available from the corresponding author on reasonable request.

\section{Authors' contributions}

ZL collected the clinical information and wrote the manuscript. ZLY supported the data collection, interpretation of the data. ZY and SBC carried out genetic studies and evaluated the mutant using expression and functional studies. ZSB and MQS were involved in revising the manuscript critically for important intellectual content. All authors read and approved the final manuscript.
Ethics approval and consent to participate

Not applicable.

\section{Consent for publication}

Written informed consent was obtained from the parents of the patient for publication of this Case Report and any accompanying images. A copy of the written consent is available for review by the Editor of this journal.

\section{Competing interests}

The authors declare that they have no competing interests.

\section{Publisher's Note}

Springer Nature remains neutral with regard to jurisdictional claims in published maps and institutional affiliations.

Received: 21 December 2017 Accepted: 11 September 2018

Published online: 21 September 2018

\section{References}

1. Pirojsakul K, Mathews N, Seikaly MG. Chronic kidney disease in children: recent update. Open Urol Nephrol J. 2015;8(1):117-23.

2. Chadha V, Warady BA. Epidemiology of pediatric chronic kidney disease. Adv Chronic Kidney Dis. 2005;12(4):343-52.

3. Woolf AS, Winyard PJ. Gene expression and cell turnover in human renal dysplasia. Histol Histopathol. 2000;15(1):159-66.

4. Aguilar A. Development: Pax2 keeps nephron progenitors on track. Nat Rev Nephrol. 2017;13(8):444.

5. Warady BA, Chadha V. Chronic kidney disease in children: the global perspective. Pediatr Nephrol. 2007;22(12):1999.

6. Kari J. Epidemiology of chronic kidney disease in children. J Nephropathol. 2012;1(3):162-3. https://doi.org/10.5812/nephropathol.8113.

7. KDIGO. 2012 Clinical Practice Guideline for the Evaluation and Management of Chronic Kidney Disease. Kidney Int Suppl. 2013;3(5-14):5.

8. Torban E, Dziarmaga A, Iglesias D, et al. PAX2 activates WNT4 expression during mammalian kidney development. J Biol Chem. 2006;281:12705-12.

9. Porteous S, Torban E, Cho NP, et al. Primary renal hypoplasia in humans and mice with PAX2 mutations: evidence of increased apoptosis in fetal kidneys of PAX2 $2^{1 \mathrm{Neu}}+/-$ mutant mice. Hum Mol Genet. 2000;9(1):1-11.

10. Negrisolo S, Benetti E, Centi S, et al. PAX2 gene mutations in pediatric and young adult transplant recipients: kidney and urinary tract malformations without ocular anomalies. Clin Genet. 2011;80(6):581-5.

11. Bower M, Salomon R, Allanson J, et al. Update of PAX2 mutations in renal coloboma syndrome and establishment of a locus-specific database. Hum Mutat. 2012;33:457-66

12. Adam J, Browning AC, Vaideanu D, et al. A wide spectrum of phenotypes in a family with renal coloboma syndrome caused by a PAX2 mutation. Clin Kidney J. 2013;6(4):410.

13. Nishimoto $K$, lijima $K$, Shirakawa $T$, et al. PAX2 gene mutation in a family with isolated renal hypoplasia. J Am Soc Nephrol. 2001;12(8):1769-72.

14. Benetti E, Artifoni L, Salviati L, et al. Renal hypoplasia without optic coloboma associated with PAX2 gene deletion. Nephrol Dial Transplant. 2007;22:2076-8

15. Xu HE, Rould MA, Xu W, Epstein JA, Maas RL, et al. Crystal structure of the human Pax6 paired domain-DNA complex reveals specific roles for the linker region and carboxy-terminal subdomain in DNA binding. Genes Dev. 1999;13:1263-75.

16. Alur RP, Vijayasarathy C, Brown JD, Mehtani M, Onojafe IF, et al. Papillorenal syndrome-causing missense mutations in PAX2/Pax2 result in Hypomorphic alleles in mouse and human. PLoS Genet. 2010;6(3):e1000870. https://doi. org/10.1371/journal.pgen.1000870. 
17. Dressler GR, Douglass EC. Pax-2 is a DNA-binding protein expressed in embryonic kidney and Wilms tumor. Proc Natl Acad Sci U S A. 1992;89(4): 1179-83.

18. Dressler GR, Wilkinson JE, Rothenpieler UW, et al. Deregulation of Pax-2, expression in transgenic mice generates severe kidney abnormalities. Nature. 1993;362(6415):65-7.

19. Ostrom L, Tang MJ, Gruss P, et al. Reduced Pax2, gene dosage increases apoptosis and slows the progression of renal cystic disease. Dev Biol. 2000; 219(2):250-8.

20. Sato T, Tashiro K, Zaitsu M, et al. Human PAX2 mutation syndrome (renalcoloboma syndrome): report of a case. Nihon Shoni Jinzobyo Gakkai Zasshi. 2000;13:125-30.

21. Dureau P, Attie-Bitach T, Salomon R, et al. Renal coloboma syndrome. Ophthalmology. 2001;108(10):1912-6.

22. Chung GW, Edwards AO, Schimmenti LA, et al. Renal-coloboma syndrome: report of a novel PAX2 gene mutation. Am J Ophthalmol. 2001;132(6):910-4.

23. Higashide T, Wada T, Sakurai M, et al. Macular abnormalities and optic disk anomaly associated with a new PAX2 missense mutation. Am J Ophthalmol. 2005;139(1):203-5.

24. Fletcher J, Hu M, Berman Y, et al. Multicystic dysplastic kidney and variable phenotype in a family with a novel deletion mutation of PAX2. J Am Soc Nephrol. 2005;16(9):2754-61.

25. Cheong HI, Cho HY, Kim JH, et al. A clinico-genetic study of renal coloboma syndrome in children. Pediatr Nephrol. 2007;22(9):1283-9.

26. Samimi S, Antignac GC, Lacombe D, et al. Bilateral macular detachment caused by bilateral optic nerve malformation in a papillorenal syndrome due to a new PAX2 mutation. Eur J Ophthalmol. 2008;18(4):656.

27. Tagami M, Honda S, Morioka I, et al. Bilateral optic disc anomalies associated with PAX2 mutation in a case of potter sequence. Case Rep Ophthalmol. 2010;1(2):94-8.

28. Hoefelea J, Gabert M, Heinrich U, et al. A novel interstitial deletion of 10q24. 2 224.32 in a patient with renal coloboma syndrome. Eur J Med Gen. 2012; 55(3):211-5.

29. Laimutis K, Jackson C, Xu X, et al. Typical renal-coloboma syndrome phenotype in a patient with a submicroscopic deletion of the PAX2, gene. Am J Med Genet A. 2012;158(6):1437.

30. Okumura T, Furuichi K, Higashide T, et al. Association of PAX2 and other gene mutations with the clinical manifestations of renal Coloboma syndrome. PLoS One. 2015:10(11):e0142843.

31. Iwafuchi Y, Morioka T, Morita T, et al. Diverse renal phenotypes observed in a single family with a genetic mutation in paired box protein 2. Case Re Nephrol Dial. 2016;6(1):61-9.

Ready to submit your research? Choose BMC and benefit from:

- fast, convenient online submission

- thorough peer review by experienced researchers in your field

- rapid publication on acceptance

- support for research data, including large and complex data types

- gold Open Access which fosters wider collaboration and increased citations

- maximum visibility for your research: over $100 \mathrm{M}$ website views per year

At $\mathrm{BMC}$, research is always in progress.

Learn more biomedcentral.com/submissions 